\title{
AUSTRALIAN DiRECTORS' DUTIES: WHAT DOES IT MEAN TO SAY THEY ARE PUBLIC DUTIES?
}

\author{
Dimity Kingsford-Smith*
}

\begin{abstract}
This article pursues the meaning and effect of what are (in Australia, at least)long-standing public duties of directors. It argues that there has been and continues to be, a slow evolution from an exclusively private character, to a hybrid public and private content in Australian directors' duties. That duties may be both public and private, does not deny the truth of either of those characters. Instead, using the statutory duty of care in s 180(1) of the Corporations Act, this article analyses the juristic features and public elements that animate the duty and its enforcement sanctions. The cardinal legal and practical question of to whom the public directors' duties are owed, both to no one in particular and to all the world, rather than only to the company, is also considered.
\end{abstract}

\section{INTRODUCTION}

In writing about how moral revolutions happen, the philosopher Kwame Anthony Appiah observes that "at the end of [a] moral revolution, as at the end of a scientific revolution, things look new. Looking back, even over a single generation, people ask, 'What were they thinking? How did we do that for all those years?"'1

Rather than a revolution, my argument here is that there is an evolution underway in the way we think about directors' duties. The law now recognises, in various ways, that interests greater than those of the commercial entity of a company may be (and sometimes must be) considered and advanced by boards. This is instead of directors' decisions turning on exclusively private corporate interests,

* MinterEllison Professor of Risk and Regulation, Faculty of Law and Justice, University of New South Wales. Correspondence to Professor Kingsford Smith: d.kingsfordsmith@unsw.edu.au. The author acknowledges the support of the Centre for Law Markets and Regulation at UNSW Law. Professor Kingsford Smith is grateful for the research assistance of Wee-Ann Tan, Katherine Chow, Samantha Wong and for the comments of participants at the Supreme Court of New South Wales Corporate and Commercial Law Conference in 2018 at which an earlier version of this article was presented.

1 Kwame Anthony Appiah The Honor Code: How Moral Revolutions Happen (WW Norton \& Company, New York, 2010) at xi-xii. 
primarily of the shareholders. Indeed, the law has recognised the public content of directors' duties for a long time and the fact that they are public duties has been recognised in recent judicial decisions of superior authority. ${ }^{2}$

In the community, in organised civil society and some parts of the business world, it is expected that directors may and even should take wider interests into account in the management of corporations. This expectation was manifest in a term of reference and prominent theme of the Australian Royal Commission into Misconduct into the Banking, Superannuation and Financial Services Industry. The Commissioner was directed to consider whether banks' conduct to customers met community standards and community expectations. It is also evident in aspirational and quasi-legal ideas such as the "social licence to operate" 3 and in the many codes, indices and transnational principles that constitute ideas and practices of corporate social responsibility. ${ }^{4}$ The moral evolution can also be observed in a recent statement by Catherine Livingstone, the Chair of the board of the Commonwealth Bank of Australia (CBA). Acknowledging that there were too many instances of CBA's interests being put ahead of customers, she said: "too often, a focus on profitability disadvantaged some of our customers. We agree that this imbalance is not acceptable." ${ }^{5}$ She went on to say that the board's strategy is to become "a simpler, better bank that delivers balanced and sustainable outcomes for our

2 Australian Securities and Investments Commission (ASIC) v Cassimatis (No 8) [2016] FCA 1023, (2016) 336 ALR 209 at [478], [503] per Edelman J [Cassimatis] as affirmed in Cassimatis v Australian Securities and Investments Commission (2020) 376 ALR 261 at [82], [140] [Cassimatis (2020)] (as "a matter of public law, not just a matter of the law of private rights"), and [27] (at the least as a matter of "public concern not just private rights"). On 5 August 2020, the High Court of Australia refused Emmanuel and Julie Cassimatis leave to appeal: Cassimatis v Australian Securities and Investments Commission [2020] HCASL 159.

3 Mark Carney "Building Real Markets for the Good of the People" (Bank of England Governor's Mansion House Speech, 10 June 2015) <www.bankofengland.co.uk>; Justin O'Brien and others "Professional Standards and the Social License to Operate: A Panacea for Finance or an Exercise in Symbolism?" (2015) 9(4) Law and Financial Markets Review 283; and ASX Corporate Governance Council Review of the Corporate Governance Council's Principles and Recommendations (Consultation Paper, 2 May 2018) $<$ www.asx.com.au $>$.

4 Tom Campbell "The Normative Grounding of Corporate Social Responsibility: A Human Rights Approach" in Doreen McBarnet, Aurora Voiculescu and Tom Campbell (eds) The New Corporate Accountability: Corporate Social Responsibility and the Law (Cambridge University Press, Cambridge, 2007) 529 at 529.

5 James Frost "CBA, Westpac Admit Pursuit of Profits Led to Misconduct" AfR (online ed, 7 November 2018) $<$ www.afr.com $>$. From remarks delivered by the Chair at the CBA Annual General Meeting on 7 November 2018. 
customers, community, our people and shareholders." ${ }^{6}$ A more traditional approach to board and corporate priority was expressed the year before by the CEO of CBA: ${ }^{7}$

Number one, we are very focused on doing whatever we can to create long-term value for our investors.

And number two is we know that a critical part of doing that is doing whatever we can to provide a predictable, reliable dividend.

This wider moral evolution is now a legal evolution. Directors are still required to weigh the interests that relate to the private nature of the corporation, but increasingly, they must do so by also taking account of wider moral goods, and I would argue moral goods of a public character. As this area is truly one of evolution, not revolution, many of the instances I hope to enliven this argument with are well known. My aim is to draw them together in the hopes of showing how far towards having a public character directors' duties have moved already.

Instead of debating the unarguable existence of public elements in Australian directors' duties law, here I concentrate on what I hope is a more trenchant question. What does it mean to say that directors' duties have a public quality? There are two core sub-questions: What are the nature and effect of the public character in directors' duties? And to whom do directors owe their duties with this public character?

The argument proceeds as follows. After this introduction, Part II contains a preliminary and orienting consideration of what kind of "publicness" we might identify in directors' duties. This preliminary discussion is not to make redundant the larger question of this article: What does it mean to say that Australian directors' duties are public? Rather it is to suggest a "working hypothesis", ${ }^{8}$ underlying values traditionally thought of as public to guide us as we look for signifiers of "publicness" in directors' statutory duties. As most readers are more familiar with the traditional private law conception of these duties, I do not dwell on that aspect except where comparison is useful for distilling the argument about "publicness".

Part III concentrates on three aspects in which public elements have been introduced to the law of Australian directors' duties. The first is the presence of state prosecutors and more recently a publicly funded regulator as a plaintiff in the enforcement of directors' duties. This is accompanied by the power to apply for sanctions with distinctly public purposes: to protect the public; to penalise directors found to have breached their duties; and to deter those tempted to follow suit.

6 Catherine Livingstone, Commonwealth Bank of Australia "2018 Commonwealth Bank Annual General Meeting: Chairman's Address" (press release, 7 November 2018) <www.commbank.com.au $>$.

7 Ian Narev "Speech and Q\&A" (Morningstar Individual Investor Conference Sydney, 6 October 2017) $<$ www.commbank.com.au>.

8 James Allsop "Values in Public Law" (The James Spigelman Oration, Federal Court of Australia, 27 October 2015) <www.fedcourt.gov.au> . 
The second aspect in which I argue that public elements of directors' duties can be observed is the identification of the public harm, corresponding public purposes and a wide class of beneficiaries which animate the statutory duty of care and associated enforcement arrangements. Thirdly, the text and immediate context of the statutory directors' duty of care contain juristic features which are distinctively public. For example, a duty which is a conduct standard and can be breached without causing loss. While public elements are to be found in the text and enforcement arrangements of all the Australian statutory duties of directors, I have illustrated the argument using the statutory duty of care and diligence in s 180 of the Corporations Act 2001 (Cth). This is because of its centrality to company management, the number of recently decided cases and the recent decision in Australian Securities and Investments Commission v Cassimatis (No 8) (Cassimatis). This decision discusses the question of directors' duties as public duties, with judicial candour and erudition in equal measure and where the reasoning of the trial judge has not been overruled on appeal. ${ }^{9}$

Part IV considers the cardinal issue of to whom the statutory duty of care is owed. If s 180 is truly a public duty owed by directors to no one in particular or to all the world (and this remains controversial), it is important to understand the numerous factors at play in that development and the understandable caution in an extension of such liability. Part V considers objections to this idea of public directors' duties of care and draws conclusions from the overall discussion.

\section{WHAT CONCEPTIONS OF "PUBLICNESS" PROVIDE A USEFUL WORKING HYPOTHESIS? 10}

There is a variety of responses to the very idea that it is useful to reason about the categories of "public" and "private" in relation to the law. Karl Llewellyn and the realists attacked the distinction as legally unsophisticated. They drew attention to the "widespread perception that so-called private institutions were acquiring the coercive power that had formerly been reserved to governments". ${ }^{11}$ Verkuil has said that the distinction "has been around forever, but it continues to fail as an organising

9 Cassimatis, above n 2.

10 I am grateful to my CLMR and UNSW colleague, Professor Pamela Hanrahan, in whose paper "Companies, Corporate Officers and Public Interests: Are We at a Legal Tipping Point?" (12 September 2018, on file with author) I was alerted to: Donald C Langevoort "Cultures of Compliance" (2017) 54 American Criminal Law Review 933 at 963. Langevoort suggests the idea of signs or goals of publicness.

11 Morton J Horwitz "History of the Public-Private Distinction" (1982) 130 UPaLRev 1423 at 1428. In Mary Stokes "Company Law and Legal Theory" in William Twining (ed) Legal Theory and Common Law (Blackwell, New Jersey, 1986) at 155 Stokes proposes:

if private property is to be legitimate within the framework of liberal society, it is also necessary to show that there are constraints which prevent it from becoming a source of power which threatens the liberty of the individuals or rivals the power of the state". 
principle". ${ }^{12}$ Stone's writing about corporations is more realistic about the unstable nature of the distinction and sees it as a barometer of how "societal choices" about rules change the autonomy of decision-makers over time. ${ }^{13}$ This last insight chimes well with the argument that the director's statutory duty of care in Australia is evolving a public character.

My argument is that the lines between public and private, always very changeable and subject to "back and forth", ${ }^{14}$ have created hybrid directors' duties with an evolving and increasingly mature "public" side as well as the traditional private legal relations. The distinction between public and private is "open-textured"15 but the general trend in processes and substantive standards is "for traditionally private bodies ... even business corporations - to bear the obligations once associated almost exclusively with governments". ${ }^{16}$

While public values manifest differently, one author suggests there are at least four senses in which the distinction between public and private might be understood. ${ }^{17}$ The overall effect is to diminish an entity's internal decision-making independence and to narrow the space in which an actor can be "arbitrary, capricious and prejudiced". ${ }^{18}$ Instead of the non-interventionist approach explicit in the internal management rule of companies, individual directors and boards find themselves required to consider wider interests or community standards than those recognised by the traditional private duties of boards. Critics of this imperialism of the public sphere, such as Hilmer, say that rather than encouraging "performance" this imposes "conformance" stifling for management decision-making and damaging to companies. ${ }^{19}$ Like Karl Llewellyn and the realists, those who support a greater

12 Paul R Verkuil Outsourcing Sovereignty: Why Privatisation of Government Functions Threatens Democracy and What We Can Do About It (Cambridge University Press, Cambridge, 2007) at 78.

13 Christopher D Stone "Corporate Vices and Corporate Virtues: Do Public/Private Distinctions Matter?" (1980) 130 UPaLRev 1441 at 1455.

14 At 1508. For a longer view on the changing balance between public and private, see Morton J Horwitz "History of the Public/Private Distinction" (1982) 130 UPaLRev 1423.

15 HLA Hart The Concept of Law (3rd ed, Oxford University Press, Oxford, 2012).

16 Stone, above n 13, at 1507.

17 Randy E Barnett "Forward: Four Senses of the Public Law-Private Law Distinction" (1987) 9 Harv JL \& Pob Pol'y 267.

18 Stone, above n 13, at 1489.

19 Frederick G Hilmer Strictly Boardroom: Improving Governance to Enhance Company Performance (Information Australia and The Sydney Institute, 1998) passim. 
influence of public values see those as a way to temper power ${ }^{20}$ and protect the interests of those whom private power affects. ${ }^{21}$

So, what might be the signposts of "publicness"? When government steps into a traditionally private law domain, it often concentrates on increasing accountability and responsibility of decisionmakers, commonly through changes to enforcement. A full-blooded response may not stop at reformed or extended standing rights for private parties or even the creation of offences and powers for prosecutions by the state. Rather, it may go further and include the creation, empowerment and funding of a regulator to supervise, detect, investigate and bring action against deficient decisionmakers. So, an increase in accountability and responsibility of decision-makers is usually a first sign, value or conception of "publicness".

The second sign of "publicness" is a greater opportunity for those affected by the resolutions or determinations of decision-makers to participate in or have their interests considered in the process of decision-making. This may be through greater disclosure to them of the facts, policies or arguments going into the decision-making. It may be through an opportunity to put forward their interests, their circumstances and the consequences for them of the options before the decision-maker. "Publicness" may be conceived of as a greater "voice" in the process of decision-making. ${ }^{22}$ A more conservative version of "voice" in the recognition of wider interests is the taking account of the interests of others affected by a decision which may also be captured in ideas of fairness. ${ }^{23}$ An example of this is the requirement of directors to "consider the interest" of creditors in board decisions in certain circumstances. $^{24}$

Wider purposes and scope of the benefit to be weighed in the exercise of power by a decisionmaker is the third marker of "publicness". This is the area where we encounter the idea of public harm and parallel public duty. If the legislature considers the careless management of companies to be a public harm, it may adopt wider purposes and a wider group of beneficiaries to benefit through

20 Martin Krygier "Tempering Power" in Maurice Adams, Anne Meuwese and Ernst Hirsch Ballin (eds) Constitutionalism and the Rule of Law: Bridging idealism and realism (Cambridge University Press, Cambridge, 2017) 34 .

21 Stokes, above n 11.

22 Albert O Hirschman Exit, Voice or Loyalty: Responses to Decline in Firms, Organisations and States (Harvard University Press, Massachusetts, 1972); and Langevoort, above n 10, at 963.

23 Dimity Kingsford Smith "Can There be a Fair Share? Fairness Regulation and Financial Markets" in Janis Sarra (ed) Explorations of Fairness (Peter Wall Institute for Advanced Studies, Carswell Thompson, 2013) 251.

24 Bell Group Ltd (in liq) v Westpac Banking Corporation (No 9 and No 10) [2008] WASC 239, (2008) 39 WAR 1; Westpac Banking Corporation v Bell Group Ltd (in liq) (No 3) [2012] WASCA 157, (2012) 44 WAR 1. The desirability of directors "considering the interests of creditors" is not agreed by everyone: Justice KM Hayne "Director's Duties and Companies Creditors" (2014) 38 MULR 795, passim. 
mitigation of the occurrence of that harm. This may signal, as with s 180, an intent to impose a public duty through publicly mandated processes and standards of conduct. With a public duty, the fact "that the regulated conduct may harm particular individuals is of secondary, if any, importance". ${ }^{25}$ Loss and damage to an individual or entity (usual in private law relations) need not be shown to establish liability. Of course, the same facts which enliven a breach of a public duty may also establish a private right of action if personal loss and damage to a plaintiff in an appropriate relation have occurred. This neatly illustrates the public and private hybridity that now characterises Australian directors' duties.

There are many emblems of the public domain, but the fourth and the last considered here is more demanding requirements of reasonableness and rationality. One of the changes to s 180, particularly in the Corporate Law Economic Reform Programs (CLERP) reforms enacted in 1999, was from a subjective standard of directors' conduct to one to be judged objectively taking account of accepted practice in the kind of company and responsibilities of their position. ${ }^{26}$ Rationality in director decision-making is subjected to procedural requirements in decision-making. These involve appropriate information-seeking and other steps to develop a belief in the interests of the company that only a reasonable person in their position could hold about the subject matter of their judgment or decision. ${ }^{27}$ This greater procedural rationality, as Whincop and Keyes argued more than 20 years ago, "draws implicitly from public law norms and concepts." ${ }^{28}$ In the instances just mentioned, it uses the procedures of information seeking and developing reasonable grounds for action rather than the relative freedom of the principles which previously permitted subjective decision-making and director autonomy in private law internal management.

25 Barnett "Public Law-Private Law", above n 17, at 268.

26 Corporate Law Economic Reform Program Bill 1998 (Cth), explanatory memorandum at [6.25]:

The draft provisions have been rewritten to clarify that whether the officer has breached the standard of care and diligence is determined both by regard to the corporation's circumstances and the officer's position and responsibilities within the corporation (proposed subsection 180(1)).

27 Australian Securities and Investments Commission v Rich [2003] NSWSC 85, [2003] 44 ACSR 341 [Rich] at [44] per Austin J:

The essential difference between s 180(1) and former s 232(4) is that the new section removes the reference to 'in a like position in a corporation', and inserts a reference to 'the office held by' and a reference to 'the same responsibilities' as the defendant director.

For discussion on the need to be informed about finances of the company and the general environment the company is in, see also Daniels v Anderson (1995) 37 NSWLR 438 at 505 per Clarke and Sheller JJA; and Australian Securities and Investments Commission v Healey (2011) 278 ALR 618 [Healey] at 625-626 per Middleton J.

28 Michael Whincop and Mary Keyes "Corporation, Contract, Community: An Analysis of Governance in the Privatisation of Public Enterprise and Publicisation of Private Corporate Law" (1997) 25(1) FL Rev 51 at 55. 
Public and private are changeable characterisations of degree on a spectrum with overlapping elements. I use public and private characterisations here for simplicity of argument, though theoretically and empirically it is inappropriate to treat them as on two sides of a dividing line. My argument is that s 180 is a hybrid provision, with "public" legal elements becoming increasingly important while pivotal "private" elements remain. As we shall examine, the fact that directors still owe their duties to the company, and not to the public at large, is the most important of these remaining "private" elements. Practical circumstances also remain central to which of the public and private elements of the s 180 duty predominates. It is likely that a small proprietary company used as a passive investment vehicle for family assets will have fewer triggers for its directors to consider interests external to the company and fewer occasions to consider the public interest. The boards of Australian banks stand in contrast. At the centre of the Australian economy, with 40,000 employees and millions of customers, bank boards must have regard to a broad range of interests and public-regarding matters. The law expects the decision-making processes of its directors to be both reasonable and rational.

\section{DIRECTORS' DUTIES AND THE LEGAL (R)EVOLUTION OF "PUBLICNESS"}

This article opened with Anthony Kwame Appiah's observations about moral revolutions. In that discussion, Appiah also observed that "arguments against each of the practices [that changed] were well known and clearly made a good deal" before the moral revolution occurred. "It wasn't ... that people were bowled over by new moral arguments." 29 With the "public" nature of directors' duties we are talking about a legal evolution and Appiah's insights about the gradual adoption of change apply in this setting too. In what follows, it will be clear that "publicness" in Australian directors' duties is not recent and has evolved gradually for over a century.

\section{A Increasing Accountability and Responsibility: Public Enforcement and Sanctions}

Although this article asks "what does it mean to say that directors' duties are public?", it is clarifying to recall the private duty of skill, care and diligence in its general law analogue. ${ }^{30}$ In the long-standing and familiar private duty, the director owes their duty to the company. Usually, though infrequently, it is the company that enforces the duty if it is breached. In Australia, in terms of private enforcement, it is not only shareholders who, standing in the shoes of the company, might sue directors. ${ }^{31}$ Private enforcement on behalf of the company may also be initiated by company officers,

29 Appiah, above n 1, at xii.

30 At xii.

31 Corporations Act 2001 (Cth), s 236. 
ex-officers, ${ }^{32}$ and liquidators. ${ }^{33}$ Widening the class of plaintiffs who may enforce the company's rights beyond the shareholders modestly increases the prospects for enforcing directors' duties. As with traditional actions by the company for duty breaches by directors, such actions are infrequent and confront numerous obstacles. ${ }^{34} \mathrm{~A}$ final signature requirement of establishing the director's breach of duty on the private side is that loss or damage was suffered by the company caused by the breach of duty.

\section{Public enforcement}

Public enforcement of directors' duties, including the duty of care, began early in Australia. As Langford, Ramsay and Welsh point out, public enforcement of this duty began with the introduction of an offence in 1958, ${ }^{35}$ providing for prosecution of a duty which in its original form had entered the law in $1896{ }^{36}$ As Nettle J observes, it was from 1958 "that directors' duties were to be thought of and enforced as part of the public law, and not just part of the law of private obligations." ${ }^{37}$ Public prosecution of directors' duties, though since 1999 not of the duty of care, continues today. ${ }^{38}$

The introduction of Australian Securities and Investments Commission (ASIC) powers for civil enforcement of directors' duties in $1993,{ }^{39}$ including the duty of care, ${ }^{40}$ is perhaps the most obvious and unique feature of the evolving "publicness" of Australian directors' duties. In the comparable

32 Section 236

33 Sections 588M and 588P.

34 Abe Herzberg "Why Are there So Few Insolvent Trading Cases?" (1998) 6(2) Australian Insolvency Law Journal 77.

35 Rosemary Teele Langford, Ian Ramsay and Michelle Welsh "The Origins of the Company Directors' Statutory Duty of Care" (2015) 37(4) Syd LR 489 at 490

36 At 492: in reference to their discussion of the 1896 provision and the fact that there was no public enforcement mechanism.

37 Justice Geoffrey Nettle "The Changing Position and Duty of Company Directors" (2018) 41 (3) MULR 2 at 8.

38 Corporations Act (Cth), s 184.

39 Sections $1317 \mathrm{E}$ and $1317 \mathrm{~J}(1)$.

40 The Corporate Law Reform Act 1992 (Cth) introduced the concept of civil penalties into the corporations law. The civil penalty provisions were introduced into the former Corporations Law Pt 9.4B by amendments which took effect in 1993. 
jurisdictions of the $\mathrm{US}^{41}$ and the $\mathrm{UK},{ }^{42}$ while directors' duties are prosecuted, there are fewer avenues for public civil enforcement of directors' duties, generally privately enforced. Empowering ASIC as a plaintiff makes available public resources for civil enforcement: this is particularly salient for the statutory duty of care which is at the heart of company management with no prosecution power. This has filled in the enforcement spectrum, ${ }^{43}$ enforcing director accountability and responsibility may more consistently and proportionately respond to the culpability of the case. ${ }^{44}$ This contrasts with depending on the contingencies of private enforcement. Instead, enforcement is governed by a publicly consulted and disclosed enforcement policy, which should guide the public regarding the rationality of enforcement decisions. In the 25 years since enactment, public civil enforcement of the statutory duty of care has become an important influence on Australian corporate governance, its directors and its officers. ${ }^{45}$ This is particularly so of large listed Australian companies, where sometimes the entire board has been sued. ${ }^{46}$

\section{Public sanctions}

The public character of regulatory enforcement of the statutory duty of care is deepened by the nature and purposes of the civil sanctions that ASIC may apply for. All of the statutory directors' duties, including the duty of care, are civil penalty provisions. Civil penalty actions are so-called because breaches of duty are required to be proved according to the rules of civil procedure and evidence, yet may result in sanctions that are personal and share some qualities of criminal or "penal" sanctions. For example, the making of a declaration of contravention of a civil penalty provision shares aspects of the public denunciation inherent in a finding of guilt in criminal proceedings. ${ }^{47}$ It requires specification of the person who contravened the provision and particulars of the conduct

41 Hilary A Sale and Robert B Thompson "Market Intermediation, Publicness, and Securities Class Actions" (2015) Georgetown Law Faculty Publications and Other Works 1526; and Marc I Steinberg The Federalization of Corporate Governance (Oxford University Press, Oxford, 2018).

42 Directors Disqualification Act 1986 (UK), which is now the Companies Act 2006 (Strategic Report and Directors' Report) Regulation 2013 (UK).

43 Australian Securities and Investments Commission Information Sheet 151-ASIC's approach to enforcement (September 2013) at 5-6; and Australian Law Reform Commission Principled Regulation: Federal Civil and Administrative Penalties in Australia (ALRC Report 95, December 2002).

44 Rather than having to choose between the poles of criminal prosecution (reserved for the most serious transgressions) or negotiated sanctions, such as enforceable undertakings (involving no admission of wrongdoing) - neither of which may be appropriate.

45 Shafron v Australian Securities and Investments Commission [2012] HCA 18, (2012) 247 CLR 465.

46 Australian Securities and Investments Commission v Hellicar [2012] HCA 17, (2012) 247 CLR 345 [Hellicar]; Healey, above n 27.

47 Corporations Act 2001 (Cth) s 1317E(1). 
which constituted the contravention. ${ }^{48}$ Likewise, a pecuniary penalty order shares aspects of fines as criminal sanctions. ${ }^{49}$ While disqualification ${ }^{50}$ consequent upon a finding of breach of a civil penalty provision does not involve a custodial sentence, it is considered penal. ${ }^{51}$ Both disqualification and custody share a purpose and effect of protecting the public from further damage by removing the liable director from the management of companies. ${ }^{52}$ Further emphasising the public nature of civil penalty enforcement against directors, only ASIC has standing to apply for civil penalty orders consequent upon a declaration of contravention. ${ }^{53}$ By contrast, compensation, which may also be obtained against directors on application by a corporation under s 180 , is a statutory remedy similar in nature to general law damages for breach of duty. ${ }^{54}$

Concentrating on the public aspects to be considered in director disqualification, it has been held that the class of persons whom disqualification is to protect is wider than shareholders and, at the very least, includes creditors and potential creditors. ${ }^{55}$ Protection for the public also includes consumers and individuals who deal with a company, ${ }^{56}$ such as suppliers or employees. It is not to be limited to the commercially unsophisticated, nor limited to public companies. ${ }^{57}$ The interest of protecting the public should be paramount and outweighs the hardship to the disqualified director or officer. ${ }^{58}$ The more serious the contravention (for example, involving dishonesty), the longer the term of disqualification and the greater the weight to be given to the risk of return to old practices should the

48 Corporations Act (Cth), s 1317E(2).

49 Section s $1317 \mathrm{G}$. A sanction originally conceived as a type of "civil fine" but now characterised as invoking privileges against penalties, see: Rich v Australian Securities and Investments Commission (ASIC) [2004] HCA 42, (2004) 220 CLR 129 [Rich (2004)] at [30]-[38].

50 Given standing at Corporations Act 2001 (Cth) s 206C(1)(a)(i) and the availability as a civil sanction confirmed at Corporations Act 2001 (Cth) s 1349.

51 Rich (2004), above n 49, at [44] per McHugh J:

[e]lements of retribution, deterrence, reformation and mitigation as well as the objective of the protection of the public in here in the orders and periods of disqualification made under the legislation.

52 Australian Securities and Investments Commission ASIC's Approach to Enforcement (Information Sheet 151, 2018) at 6.

53 Corporations Act (Cth), s 1317J(1).

54 Section $1317 \mathrm{~J}(2)$ and also in the alternative on the traditional general or common law principles and remedies.

55 Australian Securities and Investments Commission v Adler [2002] NSWSC 483, (2002) 42 ACSR 80 [Adler] at [77]-[85].

56 At [79].

57 At [85]-[86].

58 At [80] and [87]. 
period of disqualification be short. ${ }^{59}$ In these circumstances, it should be remembered that disqualification is protective for the public, both current and in the future. ${ }^{60}$ General deterrence is also relevant, ${ }^{61}$ but the protective purpose is distinctly primary. ${ }^{62}$

Complex characterisations have been offered to distinguish the "protective" character of sanctions for breach of directors' duties in comparison with their "penal" character, ${ }^{63}$ a character particularly prominent when prosecuted as offences. As the majority of the Australian High Court observed: 64

Just as a law may bear several characters, a proceeding may seek relief which, if granted, would protect

the public but would also penalise the person against whom it is granted. That a proceeding may bear

several characters does not deny that it bears each of those characters.

In a complementary way, the wider insight pursued here is that the regime of Australian statutory directors' duties, particularly the standing and enforcement aspects, constitutes a scheme of regulation comprising varying degrees of public and private.

The public character of Australian directors' duties is most intense where prosecution of a director is the avenue chosen, though this does not apply to the statutory duty of care. All the defendant's protections and privileges of the criminal law are available and prosecutorial independence is maintained by having proceedings brought not by ASIC, but by the Commonwealth Director of Public Prosecutions. At the other end of the scale, corporations may bring private statutory actions against directors for compensation for breach of duty without a declaration of contravention. ${ }^{65}$ Here the plaintiff is the company or a liquidator, ${ }^{66}$ and civil rules of evidence and procedure apply. The plaintiff corporation must prove that it has suffered loss. The compensation has no penal quality: it is not for contumelious disregard of the plaintiff's interests,${ }^{67}$ and is not in the nature of exemplary damages. Neither the measure nor its purposes are expressed to be for specific or general deterrence. The statutory compensation is a remedy in this setting, not a sanction, and is restorative in nature.

59 At [56].

60 At [80] and [87].

61 At [56] and [126]

62 At [60].

63 Rich (2004) above n 49.

64 At [35] per Gleeson CJ and Gummow, Hayne, Callinan and Heydon JJ relying on Julius Stone Legal System and Lawyers' Reasonings (Stanford University Press, California, 1964) 248.

65 Corporations Act (Cth), s $1317 \mathrm{H}$.

66 The shareholders, current or past officers under the Corporations Act (Cth), s 236 or the liquidator of an insolvent company under the Corporations Act (Cth) s 588M.

67 Ali v Hartley Poynton Ltd [2002] VSC 113, at [593]-[630]. 
In between, an ASIC action for a civil penalty order is a hybrid of public purposes and civil procedure and rules of evidence. The debate over whether the sanctions of pecuniary penalty order (civil fine) and director disqualification are penal or protective of the public only serves to further emphasise the overall public purposes of statutory directors' duties and the linked civil penalty regime. ${ }^{68}$ It is well understood that alongside disqualification or banning for public protection, penal purposes are also for the benefit of the public. ${ }^{69}$ To the extent that punishment or retribution are effective specific or general deterrents, they too have public protective purposes, as does defendant reform. ${ }^{70}$ Greater personal accountability and responsibility are sought than can be achieved by directors' duties at general law. Likewise, a wider range of public purposes is pursued, by contrast with when compensating corporate loss and damage.

\section{B Public Harms, Public Interests and Public Purposes: The Wider Context of the Statutory Duty of Care}

One of the signposts of the public quality of a law or sanction, as noted above, is that it addresses a public harm or has a widespread beneficial public purpose. Because the harm is potentially widespread, the corresponding public purpose or public interest served by the law or sanction may also be wide.

\section{Public harms and statutory purposes}

Since its original enactment in 1896, the director's statutory duty of care has addressed a potentially wide public harm; the misuse of the corporate form. Addressing this public harm has become an even clearer purpose with the introduction of civil penalties and accompanying statements about the wide public interest in better enforcement. Both the 1896 and subsequent 1958 versions of the statutory duty of care were responses to corporate frauds. ${ }^{71}$ In both cases, those supporting the enactments thought "something must be done to protect the public"72 and that clearly setting out the principles to govern directors' duties in the provisions "would be a deterrent to misconduct"73 by directors and officers, and by inference that such deterrence would be for the benefit of the public.

68 Rich (2004), above n 49, at [35].

69 Rich (2004), above n 49

70 Robert Baldwin "The New Punitive Regulation" (2004) 67 MLR 351; and Andrew Ashworth and Lucia Zedner "Prevention and Criminalisation: Justifications and Limits" (2012) 15(4) New Crim L Rev 542.

71 Langford, Ramsay and Welsh, above n 35, at 492. See note 19.

72 At $493, \mathrm{n} 29$.

73 At 504, n 91. 
The 1958 text was re-enacted as s 124 of the Uniform Companies Act 1961-1962 74 and then replaced by s 229(2) of the Companies Act 1981 (Cth). ${ }^{75}$ It was enacted yet again without material amendment as s 232(4) in 1989. ${ }^{76}$ As far as can be found, there is no further substantial comment on the purposes of the statutory duty and the public harm to be addressed in any of these numerous reenactments until further changes were made in 1992.

In 1992 two recommendations to amend the statutory duty of care by a Senate Committee were amongst those adopted by the Australian Government. ${ }^{77}$ One recommendation enacted provided that the statutory duty of care should be objective. ${ }^{78}$ The other was the introduction of civil penalty provisions with the sanctions already discussed. In adopting the Senate's recommendation for the introduction of the civil penalty sanctions, the Government said: ${ }^{79}$

The Government considers that the law relating the duties and obligations of company directors is one of central importance, affecting as it does the interests of shareholders, directors, creditors, employees and the general community.

In his Second Reading Speech, the Attorney-General stated: ${ }^{80}$

The Bill also provides that where a director breaches his or her duty, but is not acting with any dishonest or fraudulent intent, the director should no longer be exposed to criminal sanctions and possible gaol terms. But it also says that shareholders should be protected against breaches by the substitution of appropriate civil penalties, including pecuniary penalties and disqualification in the case of serious breaches.

Here the Attorney-General seemed to be arguing that, as a matter of enforcement discretion, directors should not be exposed to criminal penalties unless dishonest. Otherwise, civil penalties were appropriate to protect investors and the public.

74 Nettle, above n 37 , at 8.

75 As applied to NSW by the Companies (Application of Laws) Act 1981 (NSW), in operation from 1 July 1982.

76 Section 232(4) came into existence without material change from the previous s 229(2) in the Corporations Act 1989 (Cth). Substantial changes were made to s 232(4) to clarify that the standard of care was objective, by the Corporate Law Reform Act 1992 (Cth).

77 Senate Standing Committee on Legal and Constitutional Affairs Company Directors' Duties (PP 395, November 1989).

78 Corporate Law Reform Act 1992 (Cth) enacted a new s 232(4), which reinforced that the duty of care is an objective one.

79 (28 November 1991) 149 AUPD 3611-3620.

80 (3 November 1992) 155 AUPD 2400 per Hon Michael Duffy. 
However, the issue of removing criminal prosecution for breach for the duty of care remained on the legislative agenda. In 1999, criminal penalties for a contravention of the statutory duty of care and diligence were finally removed and civil penalties remained. ${ }^{81}$ In the same enactment, a business judgment rule was introduced in s 180(2) and s 232(4) was replaced with s 180(1). ${ }^{82}$

In 2001, the text of s 180(1) produced by the legislative changes in 1999 was included in the current Corporations Act 2001 (Cth) without material change, and after a long history, has not been altered by the Parliament for nearly 20 years.

\section{Judicial recognition of public harms and public interests}

The fact that Australian directors' duties serve public purposes which may address public harms has also been observed by the courts, though this has been expressed in differing ways. Sometimes public purposes or the public interest is found in the proper management of companies. For example: ${ }^{83}$

Section 180(1) imposes a statutory duty much like the duty at common law. Its public policy value is to ensure that boards of directors of companies are composed of individuals with suitable skills to monitor the actions of management and to perform any special tasks for which they are appointed.

At other times the public interest in directors' compliance with their duties is identified as the delivery of accurate information to the market and the public: ${ }^{84}$

... the public was misled. The public was led to believe there were sufficient funds in the Foundation to meet all legitimate present and future asbestos claims. That was not so. That is a serious matter. The market was acting on a false premise.

In a similar vein: ${ }^{85}$

The managing director must not mislead the board or withhold material information from it, and is also responsible for ensuring that the ASX and the investing public are properly and accurately informed. The managing director must be rigorous in ensuring that there is a reasonable factual basis for public statements on behalf of the company, especially statements that might influence the share price.

81 Corporate Law Economic Reform Program Act 1999 (Cth).

82 Corporate Law Economic Reform Program Act 1999 (Cth).

83 Australian Securities and Investments Commission v Macdonald (No 12) [2009] NSWSC 714, (2009) 259 ALR 116 at [99] per Gzell J.

84 At [358].

85 Australian Securities and Investments Commission (ASIC) v Rich [2009] NSWSC 1229, (2009) 75 ACSR 1 [Rich (2009)] at [7219]. 
Following this comment on the obligations of the managing director, in the same case, Austin J made remarks to similar effect in relation to the finance director. ${ }^{86}$

Sometimes a wider and more variegated version of the public interest in the duties of directors is identified by the courts: ${ }^{87}$

A director is an essential component of corporate governance. Each director is placed at the apex of the structure of direction and management of a company. The higher the office that is held by a person, the greater the responsibility that falls upon him or her. The role of a director is significant as their actions may have a profound effect on the community, and not just shareholders, employees and creditors.

At other times the courts identify a public interest in the proper enforcement of sanctions against errant directors, primarily through the civil penalty provisions: ${ }^{88}$

ASIC as plaintiff is acting as an agency of the Commonwealth and not as a private litigant, and like the prosecutor in criminal proceedings, is the guardian of the public interest with a responsibility to ensure that justice is done.

Likewise: ${ }^{89}$

ASIC is not seeking to right a wrong to AWB. It is pursuing the public good of seeking to punish the defendants for their alleged contravention of their duties as officers of AWB.

A particular public purpose of enforcement noted by the courts is the protection of the public, ${ }^{90}$ especially as investors: ${ }^{91}$

The law is concerned with the protection of investors by endeavouring to ensure that the information upon which they make their investment decisions is materially accurate and complete. Issues of high public policy are involved.

The law is also concerned with public protection more widely including individuals who deal with companies, including consumers, creditors, shareholders and investors. ${ }^{92}$ In particular, orders disqualifying directors "are orders designed to protect the public from the harmful use of the corporate

86 At [7223].

87 Healey, above n 27, at [14]

88 Rich (2009), above n 85, at [533].

89 Australian Securities and Investments Commission (ASIC) v Flugge; sub nom Re AWB Ltd (No 1) [2008] VSC 473, (2008) 252 ALR 566 at [101].

90 See discussion above surrounding above n 58 and n 59.

91 Australian Securities and Investments Commission v Vines [2005] NSWSC 738, (2005) 55 ACSR 617 [Vines] at [1078].

92 Australian Securities Commission v Roussi [1999] FCA 618, (1999) 32 ACSR 568 at [13]. 
structure or from use that is contrary to proper commercial standards."93 As well as protection of the public, since the High Court's decision in Australian Securities and Investments Commission v Rich, it has also been recognised that disqualification orders are penal in nature and deterrent in effect, which may also have protective effects in the public interest. ${ }^{94}$

Sometimes a mix of the public interest purposes of s 180(1) and enforcement by civil penalty provisions is referred to: ${ }^{95}$

The concepts of public interest, public policy and commercial reality in the context of corporate governance encompass considerations of community confidence in the management of commercial businesses by directors. Various indicators point to the fact that there is a public interest in the enforcement of the duties owed by directors to their companies. Indeed, the role of the State (via ASIC) in the enforcement of statutory duties, the existence of civil penalty provisions, and the ability for directors to be held criminally liable for their actions, confirms the recognition of a public interest in the enforcement of directors' duties.

Finally, in Australian Securities and Investments Commission v Adler, Santow J conducted a wide-ranging review of the mix of public interests involved in directors' duties, including that under s $180(1)$, and the civil penalty provisions. ${ }^{96}$

\section{The public purposes and public interest expressed in ASIC's enforcement policy}

The enforcement policy of ASIC also considers the purposes of and public interest in directors' duties. ${ }^{97}$ A leading consideration is the nature of the conduct and the extent of the harm or loss caused by any suspected breach. Does this "impact on market integrity or the confidence of investors and financial consumers ... the amount of money lost and the impact of that loss on the people affected"? 98 Here the public interest is in a safe and orderly market and in mitigating the human impact of large financial losses on a wide range of participants. Another factor is whether "misconduct is widespread or part of a growing trend, and whether taking enforcement action will send an effective message to the market". ${ }^{99}$ ASIC makes plain that its enforcement decisions are conditioned by choosing the best

93 Australian Securities and Investments Commission v Hutchings [2001] NSWSC 522, (2001) 38 ACSR 387 at 395.

94 Rich (2004), above n 49, at [44] per McHugh J.

95 International Swimwear Logistics Ltd v Australian Swimwear Company Pty Ltd [2011] NSWSC 488 at [106].

96 Adler, above n 55, at [56], and [79]-[80] per Santow J.

97 Australian Securities and Investments Commission, above n 43.

98 At 4.

99 At 4. 
remedy for a specific context whilst juggling many considerations, including: regulatory cost and effectiveness; a balance of protective and penal purposes; and formal enforcement and negotiated avenues for resolution. ${ }^{100}$

The nature and content of this polycentric enforcement discretion are quintessentially public, a conclusion reinforced by the widespread character of its intended beneficiaries. It contrasts sharply with the singularity of private enforcement of directors' duties seeking recovery of loss. Those actions brought by the company, or in its name, are in the interests of the corporation in proper internal management and derivatively in the financial interests of its shareholders and creditors.

\section{Increasing Reasonableness and Rationality: Text of the Statutory Directors' Duty of Care in s 180(1)}

To this point we have concentrated on the public enforcement and sanctions, the public harm, public purposes and public interest in the proper discharge of the duty of care in s 180 of the Australian Corporations Act 2001 (Cth). Now it is appropriate to turn to the text of the statutory duty of care itself and its place in the enactment overall to examine the changes in the standards of reasonableness and rationality the section requires. The reader will recall the opening argument that increasing requirements of reasonableness and rationality may signal an increase in the public character of a duty.

\section{The text of the director's statutory duty of care}

It is commonplace that general law (common law and equity) duties may co-exist with statutory analogues. Often the latter are created to reform the general law: to clarify principles and concepts; to have the law better resonate with current commercial standards or community expectations; or to overcome obstacles to the practical enforcement of rights and duties. ${ }^{101}$ In the past, it has been said that the statutory directors' duties, including that of care, are substantially the same as general law directors' duties. However, it is now understood that the text of s 180 imposes a statutory duty of care on Australian directors in concepts and terms with significant differences to those in the general law duty. To this we now turn.

The text of s 180(1) provides that the duty of a director or officer of an Australian corporation must "exercise their powers and discharge their duties with the degree of care and diligence that a reasonable person would exercise" and is open and general. The duty is nowhere expressed to be in relation to any beneficiary or owed to any entity. In particular, the text of the section does not expressly state that the duty of care is owed to the company. Nor does the statutory text restrict the "powers" to be exercised and "duties" to be discharged by directors to the private kind derived from a corporate

100 At 4.

101 Dimity Kingsford Smith "Interpreting the Corporations Law - Purpose, Practical Reasoning and the Public Interest" (1991) 21 Sydney L Rev 161. 
constitution. The text leaves open and general the possibility, indeed the modern reality, that directors will be required to exercise powers and discharge duties under general and statute law derived otherwise than from the corporation. ${ }^{102}$ This, of course, includes powers and duties other than from the Corporations Act 2001 (Cth) itself. Many of these general powers and duties are public in nature and owed to the public or sections of it. Of example, employees of or investors in the corporation and the corporation's customers as consumers.

The discussion in Australia of the public character of directors' duties, specifically in relation to the duty of care, has been elevated since the Federal Court decision in Cassimatis in late 2016. ${ }^{103}$ There it was held that: ${ }^{104}$

Private wrongdoing is relational. It involves a breach of duty in relation to another person... This principle of private law does not apply to public duties. A public duty to take care can and often does arise without being in relation to a person. There are few, if any, places in the world where a person who drives at $200 \mathrm{~km}$ per hour on a public road does not seriously breach a legislated public duty. If no person is damaged then no private duty to a person is breached. But the public duty is breached.

Section 180(1) is often described as "an objective normative standard of the degree of care and diligence directors must attain", ${ }^{105}$ or in other words, a conduct standard. The public element is recognisable in the greater reasonableness and rationality required to discharge the standard. The section mandates an objective standard judged against the reasonable conduct of a director in a like corporation with like responsibilities and in like circumstances. As discussed above, one purpose of the enactment of what is now s 180(1) was to confirm this objective standard with its requirements of reasonableness in decision-making and conduct. While allowing for the variety of companies, management responsibilities and arrangements for the delegation and exercise of authority within a company, s 180(1) provides an objective standard of care and diligence for both directors and officers. ${ }^{106}$ This is higher and more consistent, and being a knowable standard, can be adduced in expert evidence. In these ways, the s 180(1) standard is more rational than the older subjective

102 Cassimatis, above n 2, at [470].

103 At [470].

104 At [451]-[452].

105 Cassimatis, above n 2 at [27] per Greenwood J (emphasis added).

106 Corporations Act 2001 (Cth), s 180(1)(a) and (b). Directors and officers may not argue a lack of skill or experience to avoid liability and their duty of care is influenced by the circumstances: Vines, above n 91, at [1085] upheld on appeal in Vines $v$ Australian Securities and Investments Commission [2007] NSWCA 75 [Vines (2007)]. 
standard ${ }^{107}$ and more appropriate for a public duty that has a potentially wide application and serious sanctions which may follow from a breach.

Also distinctive about the text of s 180(1) is the absence of a requirement to show loss to the corporation to constitute a breach of the public duty when ASIC is the plaintiff. This was observed in Vrisakis v Australian Securities Commission ${ }^{108}$ regarding a predecessor to s 180(1): unlike in private tort, liability could be found "without any damage having been sustained". ${ }^{109}$ Rather, it is only necessary to show an unreasonable risk of loss to the company. Put legally, if a reasonable director could foresee the risk but would not take it because the balance of the risk of harm, potential benefit and cost of mitigation are too great, the risk is unreasonable and should not be taken. ${ }^{110}$ As a public duty and a norm of conduct, this calculus may require consideration of wider interests, including the public interest, as well as the more traditional interests of the corporation. ${ }^{11}$ The clearest examples are judgments of liability for failure by directors to carefully and diligently monitor arrangements for corporate compliance with statutory provisions revealed by instances of corporate illegality. ${ }^{112}$ The absence of a requirement to show loss, and instead only an unreasonable risk of loss, is a departure from the private law elements of tort. More significantly for directors, it is a signpost suggesting a departure from the relational private law setting where directors need to consider only the interests of the company, to one where there are wider interests that should be taken into account.

\section{Features in the context of the statutory director's duty of care suggesting its public character}

There are several other features of the Australian directors' statutory civil penalty duty of care that suggest a public character. These features, while not always expressly in the text of the section, have a force of law derived from the statutory indicia of the duty and have been noted judicially or relied on in judicial decisions.

107 Re City Equitable Fire Insurance Co Ltd [1925] Ch 407.

108 Vrisakis v Australian Securities Commission (1993) 9 WAR 395.

109 At 449

110 At 449-450.

111 Cassimatis, above n 2, at [462] and [481].

112 The so-called "stepping stone" cases: Cassimatis, above n 2; Hellicar, above n 46; Australian Securities and Investments Commission v Mariner Corp [2015] FCA 589, (2015) 241 FCR 502; Australian Securities and Investments Commission v Fortescue Metals Group [2011] FCAFC 19, (2012) 190 FCR 364, 370; Abe Herzberg and Helen Anderson "Stepping Stones: From Corporate Fault to Director's Personal Civil Liability" (2012) 40 FL Rev 181; and Rosemary Teele Langford "Directors' Duties: Cassimatis v Australian Securities and Investments Commission [2020] FCAFC 52 - 'Dystopian Accessorial Liability" or the End of 'Stepping Stones' As We Know It?" (2017) 35 C\&SLJ 362. 
The first is that the s 180(1) duty is not, by contrast with private duties under the contractual setting of a corporate constitution, able to be excluded, waived or ratified. ${ }^{113}$ The only avenue to relief from the duty is by a court order allowing exoneration from the consequences of a breach where the director has acted honestly "and ought fairly to be excused for a contravention". ${ }^{114}$ Exoneration may be better late than never, but it is also rarely granted. ${ }^{115}$

Though few decisions relate to the duty of care, the weight of authority on ratification of statutory duty denies directors a release from the consequences of breach of the statutory conduct standards. ${ }^{116}$ Some decisions indicate the types of interests the statutory duties seek to protect and which cannot be derogated from by a vote of the shareholders in a general meeting. Ratification of a statutory duty has been denied when it would damage the rights of third parties transacting with a company, ${ }^{117}$ in part because the duty "involve[s] public rights." 118 It has also been observed that the availability of a precursor of the current s $1317 \mathrm{~S}$, expressly providing for the relief of directors from the consequences of breach of statutory duty, was further evidence that "contraventions of the civil penalty provisions cannot be ratified by shareholders." 119

Next, all the civil penalty directors' duties apply not only to directors but also extend to the very senior management of companies below board level. They apply to those who are "officers" of the corporation. ${ }^{120}$ Officers are those who make or participate in "decisions that affect the whole, or a substantial part, of the business of the corporation" or have a "capacity to affect significantly the corporation's financial standing"121 and are usually immediate delegates of the board. If harm is to be avoided to the corporation, or to the interests of the public under a public duty, it is logical that the

113 Cassimatis, above n 2, at [457]; Angus Law Services v Carabelas [2005] HCA 23, (2005) 226 CLR 507 [Carabelas] at [32]; and Forge v Australian Securities and Investments Commission [2004] NSWCA 448, (2004) 213 ALR 574 [Forge] at [378]-[383].

114 Corporations Act 2001 (Cth) s 1317S; and the shareholder consent under consideration in Australian Securities and Investments Commission v Maxwell [2006] NSWSC 1052, (2006) 59 ACSR 373 might be grounds for an exoneration rather than altering the underlying duty or forgiving a breach.

115 Cassimatis, above n 2, at [785]-[824].

116 Carabelas, above n 113, at [32].

117 Forge, above n 113, at [374]-[384], and [357]: The third-party right was either a preference shareholder or a creditor (characterisation was contested) and eventually conceded as the latter.

118 At [381] per McColl JA, Handley and Santow JJ agreeing.

119 At [382].

120 Corporations Act (Cth), s 9.

121 Section 9. 
scheme of the statutory directors' duties has been extended to executives with significant power to affect all those interests. ${ }^{122}$

Thirdly, the penal nature of some of the civil penalty consequences of breaching the statutory negligence duty already discussed has also moved the Australian courts to elevate procedural protections for director defendants, whilst proof of liability remains at the civil standard. ${ }^{123}$ The "evidence [must] give rise to reasonable and definite inference and not merely to conflicting inference of equal degree of probability". ${ }^{124}$ The New South Wales Court of Appeal rejected a higher duty of care despite the serious sanctions but affirmed a higher standard of proof, responding to the gravity of the breaches alleged and the possible consequences. This is not the criminal standard of proof but at a standard higher than the civil standard required for establishing a private tort claim. ${ }^{125}$

\section{TO WHOM MIGHT THE PUBLIC DUTY OF CARE BE OWED?}

The reader will recall that the question of this article is, "what does it mean to say that the director's duty of care is public?" To this point, we have identified a number of features surrounding the statutory duty that have been argued to be public in nature and effect. First, a greater level of public enforcement, especially by ASIC, and a modest extension in standing beyond shareholders in the statutory derivative action. Secondly, the identification of public harms in the mismanagement of corporations and responding legislative purposes, seen in authoritative pre-enactment sources, legislative policy and judicial decisions. Thirdly, the text and context of the statutory duty of care show it to be a norm of conduct which, put shortly, requires the careful and diligent management of companies taking account of wider interests as well as those of the company. If we are to conclude that s 180(1) is a public duty as these features suggest, then to whom is that public duty owed? Private law directors' duties are owed to the company and in Australian general law principle, aside from an obligation to "consider the interests of creditors" in circumstances of insolvency, ${ }^{126}$ only the shareholders' interests are required to be considered. ${ }^{127}$

This article is about legal evolution and slow changes in community standards effected through the public sphere. There is no need to see or predict a dramatic break from the current legal position that directors' duties are owed to the company, both in general law and in relation to the statutory duties. There are, however, two theatres of contemporary Australian corporate law where it is credible

122 See Explanatory Memorandum for the definition of "officer".

123 Corporations Act (Cth), s 1332.

124 ASIC v Fortescue Metals Group Ltd (No 5) [2009] FCA 1585 at [82]; see also Briginshaw v Briginshaw [1938] HCA 34, (1938) 60 CLR 336.

125 Vines (2007), above $\mathrm{n} 91$.

126 See above $\mathrm{n} 24$.

127 Above n 24. 
to suggest that changes will develop. The first is a widening of the interests, which have been held to be the interests of the company. The second is standing to sue for breach of statutory duties.

\section{A Widening of the Company's Interests Subject to the Directors' Duty of Care}

Traditionally, a public duty is owed to the world at large or, as put in Cassimatis, "often does arise without being in relation to a person" in any way nominated. ${ }^{128}$ This raises the question of whether under s 180 (1) the director's duty remains only to their company, or is owed more widely, possibly even to the world at large. In this respect, like others canvassed, the statutory terms of s 180(1) remain open and general. The discussion above about the harms envisaged, the interests protected and the legislative purposes correspond with this open language of s 180(1). Where the analogous statutory private law duty is in question, the open terms of s 180(1) are circumscribed by the requirement on the corporate plaintiff to show loss to obtain compensation. Where ASIC is the plaintiff, only an unreasonable risk of loss is required and the section is silent on the range of interests to which that risk may apply, and also to whom the duty is owed.

In Cassimatis, the defendant directors argued that as the sole shareholders, "the only interest of the company is the interest of its shareholders." 129 They argued that s 180(1) should be seen as creating a private wrong. As a private wrong, they argued that their duties should be owed to the company alone and reflect their interests in the company, primarily their financial interests. This they rightly said has been the dominant approach to the interpretation of directors' duties. They contended that consideration of wider interests should be postponed until after determination, on the narrower view, of whether their own duty to the company had been discharged or breached.

Edelman $\mathrm{J}$ did not find it necessary to depart from the traditional view that the duty of directors is owed to the company. ${ }^{130}$ Rather, the director's duty to the company is wider than the duty to consider shareholder interests. ${ }^{131}$ The correct question to ask, since directors owe their duties to the company, is "what damage (if any) did it suffer ... The question is not whether the shareholders ... were adversely affected ...". ${ }^{132}$ He went on to hold that the shareholder directors' duty to consider the interests of their company "does not require a narrow construction of ... interests which is limited only to the interests of the shareholders. ... [the] interests should not be construed narrowly."133 Specifically relevant to the argument here, he concluded that "the broad terms of the legislation do

128 Cassimatis, above n 2, at [452].

129 At [446].

130 At [478].

131 At [520].

132 At [520] adopting words from Pilmer v Duke Group Ltd (in liq) [2001] HCA 31, (2001) 207 CLR 165.

133 At [478]. 
not confine the relevant interests of the corporation which fall for consideration."134 These include "a real and substantial interest in the lawful or legitimate conduct of its activity independently of whether the illegality of that conduct will be detected or would cause loss."135 So "non-pecuniary consequence" for a corporation may be included as interests to be protected by directors and particularly "harm to its interests including reputation". ${ }^{136}$

Edelman $\mathrm{J}$ went on to hold that breaches by the Cassimatis company of the law relating to appropriate financial advice and consequent loss to vulnerable investors were very likely to be discovered. Once discovered, the threat to the company was that ASIC would suspend or cancel the company's licence to give financial advice, which was its central business. He described the consequences of this risk to the company as "catastrophic". ${ }^{137}$ To this he added other significant and likely risks to the company arising from Cassimatis' conduct: the possibility of a banning order; remedial actions by customers; and damage to the direct interest of the company in its reputation. Aligned with the arguments about the public nature of the s 180(1) duty made above, Edelman J held that a wide range of interests in the proper management of the company might be recognised. ${ }^{138}$ Although beneficial for external parties, such as customers and the public interest in the proper administration of companies, the interests recognised as at-risk were still clearly those of the company. ${ }^{139}$

\section{B Standing to Sue for Breach of Statutory Duties}

As observed in Part III above, expansion of standing rules and the greater accountability and responsibility for decisions and conduct is one inidcator of public values in law. If a public duty is owed without being in relation to a named person, in Edelman J's example of a breach of public duty in driving at $200 \mathrm{~km} /$ hour, does that mean that anyone in the world catching a driver in the act can enforce such a public duty, regardless of loss? How would it play out if we followed this logic of public duties to the full in relation to s 180(1)? A public duty may have normative but little practical legal effect, unless it is grounded in a right, such as standing to sue. ${ }^{140}$ Unless it is accompanied by standing rights, a public duty such as s $180(1)$ remains a duty of imperfect obligation. ${ }^{141}$ Imperfect,

134 At [481]

135 At [482].

136 At [481].

137 At [774].

138 At [454]-[478].

139 At [454]-[478].

140 DN MacCormick "Rights in Legislation" in PMS Hacker and J Raz (eds) Law Morality and Society: Essays in Honour of HLA Hart (Oxford University Press, Oxford 1977) 199 at 204-205.

141 A duty of imperfect obligation is one of charity or gratitude which cannot be enforced by law. Kant makes a distinction between perfect obligations and imperfect obligations: Immanuel Kant Critique of Practical 
because though a positive norm of conduct, there is no legal means to compel the proper discharge of the duty.

The s 180 duty when enforced by ASIC is partially perfected and as argued above, wide public interests are protected by comparison with the narrower interests enforceable by a company at general law. When a company applies for compensation for breach of $\mathrm{s} 180$, the duty is further perfected in a fashion and measure similar but not identical to the general law. The same is the case where shareholders successfully obtain leave to sue for statutory compensation as derivative plaintiffs.

If a plaintiff is "a person whose interests have been, are or would be affected by conduct" constituting a contravention of the Corporations Act, including the statutory duty of care, then they may apply for an injunction. ${ }^{142}$ Standing under s 1324 is generally given a broad and remedial interpretation, 143 "consistent with the objects of the legislation in protecting the public in respect of the commercial interests of corporations". ${ }^{144}$ Standing to apply for injunctions responding to breaches of directors' duties have been granted to shareholders ${ }^{145}$ and creditors. ${ }^{146}$ Although there are practical obstacles ${ }^{147}$ and controversial limits to the remedy, ${ }^{148}$ the cases indicate that courts should consider the public interest in curtailing contraventions in deciding to grant an injunction. ${ }^{149}$

For other potential plaintiffs, the s 180(1) duty remains one of imperfect obligation. One way to vindicate s 180(1) as a public duty more widely is to assert that it implies a statutory right of action

Reason (Cambridge University Press, Cambridge, 1996). Sen applies this concept to human rights to extend the different types of obligations that a right imposes upon human agents. It is his repost to the idea that because there is no legal obligation, an obligation might be ignored: Richard H Morgan "Life, Liberty and the Pursuit of Happiness: Human Rights and Immigration" in MW Karraker (ed) The Other People (Palgrave McMillan, London 2013) 205. See also TD Campbell "Perfect and Imperfect Obligations" (1975) 52(3) The Modern Schoolman 285.

142 Corporations Act (Cth) s 1324(1).

143 Broken Hill Proprietary Co Ltd v Bell Resources Ltd [1984] 2 ACLC 57 (QSC) [Broken Hill].

144 Broken Hill, above n 143; and Stephen Bottomley and others Contemporary Australian Corporate Law (Cambridge University Press, Cambridge, 2018) at 400.

145 Broken Hill, above n 143.

146 Airpeak Pty Ltd v Jetstream Aircraft Ltd [1997] FCA 158, (1997) 23 ACSR 715.

147 If there is no likelihood of a further contravention and no injunction is available, no damages in lieu of an injunction are available either.

148 Especially in relation to damages in lieu of an injunction under s 1324(10): see McCracken v Phoenix Constructions (Qld) Pty Ltd [2012] QCA 129; though for a reconsideration of the position, see Katy Barnett "A Reconsideration of s 1324(10) of the Corporations Act 2001 (Cth): Damages in Lieu of an Injunction" (2018) 36(4) C\&SJL [S 1324(1)] 370 at 372.

149 Corporate Affairs Commission (NSW) v Lombard Nash International Pty Ltd (1986) 11 ACLR 566; and Barnett, S 1324(1), above n 148. 
against a breaching director. Speaking practically this would likely occur only when loss or damage gives reason to sue, though legally no proof of loss is required. Speaking theoretically, this could perfect the director's public duty by conferring on any individual or entity a right of action for breach of statutory duty in s $180(1)$.

Theoretical, is, however, the state in which the standing of the general public is likely to remain. In a recent review of the state of the Australian authorities for implying a private right to sue for the tort of breach of statutory duty owed to the world at large, Foster concludes: ${ }^{150}$

It is true to say that in recent years the action for breach of statutory duty has more often been denied than accepted in areas outside that of workplace safety. ... [M] ore recently the presumption now usually applied is the opposite one, at least where a penalty is prescribed by the statute: that the criminal penalty alone is deemed to be the main means of enforcement of the statutory right, unless there are good reasons ... otherwise.

Generally: ${ }^{151}$

The court finds that the implication of what Parliament has enacted is that Parliament intended to legislate for the protection of a class of persons which includes the claimant. ... One important piece of evidence tending to show that Parliament intended such protection is that the legislation makes further and better provision for protection of an already recognised 'common law' right.

As we have discussed standing to sue in common or general law is limited to the company or derivatively to shareholders and has never been available to the general public.

However, more recently, greater importance has been accorded to rights created by statute. Here the courts likewise fall back on the normal rules of statutory interpretation to establish whether there is an implication of a personal and private right of action. Overall: 152

The legitimate endeavour of the courts is to determine what inference really arises, on a balance of considerations, from the nature, scope and terms of the statute, including the nature of the evil against which it is directed, the nature of the conduct prescribed, the pre-existing state of the law, and, generally, the whole range of circumstances relevant upon a question of statutory interpretation.

As far as can be found, there have been no successful actions against directors based only on a right to sue implied from the statutory duty in s 180(1) or any of its predecessors.

150 Neil Foster "The Merits of the Civil Action for Breach of Statutory Duty" (2011) 33(1) Syd LR 67 at 73.

151 At 71. See also O'Connor v SP Bray Ltd [1937] HCA 18, (1937) 56 CLR 464 at 464 and 478 per Dixon J; and Sovar v Henry Lane Pty Ltd [1967] HCA 31, (1967) 116 CLR 397 [Sovar] at 404 per Kitto J.

152 Sovar, above n 151, at 405 per Kitto J. 


\section{PUBLIC DUTIES OF DIRECTORS? OBJECTIONS AND CONCLUSIONS}

This article asks: "what does it mean to say that directors' duties are public?" The subsidiary questions have inquired about the nature and effect of the director's statutory duty of care and to whom it is owed. Along the way it has been argued that several signposts suggest the statutory duty of care has this public quality: an increase in the accountability and responsibility of decision-makers; a greater opportunity for those affected by the resolutions or determinations of decision-makers, to participate in or have their interests considered in the process of decision-making, mostly through increases in standing; wider purposes and scope of the benefit to be weighed in the exercise of power; and finally, more demanding requirements of reasonableness and rationality in decision-making. The overall approach has been to suggest that there is a slow moral and legal evolution towards requiring company directors to take account of more public-regarding interests and matters in board decisionmaking.

In answering the question, "what does it mean to say that directors' duties are public?", it is not difficult to see the additional accountability and responsibility of directors coming from the increase in standing and more intrusive and personal nature of sanctions, which have developed since 1958 . The increase in standing over time has also provided greater opportunity, mostly for ASIC, to represent the interests of those affected by the decisions of directors, particularly investors and the public interest in properly informed markets. While modest increases in standing have been afforded to some other plaintiffs, the public duty remains one of imperfect obligation for the great majority of those whose interests might be affected in a general way by directors' decisions.

The wider purposes and scope of the director's public statutory duty of care have evolved over the last 60 years. These purposes of mitigating harm and encouraging the proper management of companies in the public, not only the private interest, have been recognised by the courts, especially in consideration of sanctions. The wider scope of the beneficiaries of the duty is also evident in the open and general text of the duty, and in its character as a conduct norm rather than solely as an avenue to liability and compensation. The Cassimatis decisions included consideration of customers as well as the shareholders and creditors, recognised in earlier decisions. Finally, in developments such as the objective standard of the statutory duty of care and the information-seeking requirements of the business judgment rule, it is possible to see a modest change towards both procedural and substantive requirements of reasonableness and rationality.

Meanwhile, the fact that both the public and private law versions of the duty of care are owed to the company, remains a significant refutation to the argument made here. In Cassimatis, Edelman J identified this feature as the leading objection to the director's duty of care being accepted as a truly public duty. ${ }^{153} \mathrm{He}$ pointed out that "the section and its predecessors are concerned with duties owed 
to the corporation". ${ }^{154}$ Further, the overall scheme of the civil penalty provisions and the text of the duty in s 180(1) expresses the obligations of the director in the same way, whether the duty is the basis of a private action for compensation (by the company), or owed publicly and enforced by disqualification or civil penalty by ASIC. On this point and interpretively, meaning continues to be found not from the signposts and norms of public law, but by using the background of general law directors' duties, which are owed to the corporation. ${ }^{155}$

Edelman $\mathrm{J}$ also noted that if the duty of care were owed to all, it "might be a very difficult duty ... to consider public interest at large which might even be contrary to the interest of the corporation". ${ }^{156}$ In the same vein, Nietsch observes that "excessive liability ... can result in disproportionate controls"157 suffocating lawful and worthwhile business endeavour. The result could be that "liability would unfairly and disproportionately subject the director to business risks that should be borne by the company itself" 158 or more accurately by its shareholders. By contrast with shareholders, the directors do not enjoy the benefits of limited liability.

Relatedly, in a regulated setting, corporate illegality will often require reporting a breach to the regulator and that in turn may after investigation reveal failures in, say, monitoring and supervision by the board. Extension of standing rights, particularly if that applied to general suit for breach of statutory duty inherent in publicness, may lead to directors not co-operating with the regulator or "even encourage the active obstruction of prosecution for corporate crime." ${ }^{159}$ This in turn might disrupt and render less effective the regulatory enforcement of the s 180(1) statutory duty.

These objections and practical reasons encourage the taking of an evolutionary approach to increasing the public quality of directors' duties as most apt for enduring legal change. However, legal change cannot lag too far behind the public's expectations of the conduct of directors' decisionmaking. The tempering of corporate power through law is an important aspect of the legitimacy of corporations and the decisions of their boards. There are reasons for optimism that the dance between the legislature, courts, regulator and board that has gone on for at least 60 years in the fashion described here will continue to incorporate other interests as the beneficiaries of the statutory directors' duty of care, with those of the company. As Appiah reminds us, (r)evolutions in values and opinions

154 At [474]

155 Kingsford Smith, above n 101.

156 Cassimatis, above n 2, at [476].

157 Michael Nietsch "Corporate Illegal Conduct and Directors' Liability: An Approach to Personal Accountability for Violations of Corporate Legal Compliance" (2018) 18(1) JSLC 151 at 153.

158 At 164

159 At 174 
occur and the history of change in the Australian directors' duty of care in the last 60 years shows too that such changes also happen in the law.

In mid-2017, the Law Faculty at the Victoria University of Wellington in New Zealand held a symposium in conjunction with Cornell Law School. The symposium was on legal personality as a tool to benefit present society, future generations and humanity. The aims and the subject matter discussed were the "extraordinary legal tools to safeguard resources and move value through time, as well as to protect legitimate private and public interests and support life-changing technological innovations" that corporations are when well managed. Through judicious regulation, it is hoped that corporations and like legal entities may "allow the protection of current economic, natural and cultural assets in the interest of present society and future generations". ${ }^{160}$ I was lucky enough to be present for that symposium, which was largely inspired by the creative mind and energy of the legal scholar, Professor Lynn Stout, Distinguished Professor of Corporate and Business Law at Cornell Law School. I hope this article contributes to thinking about the public interest in corporations and the interests of their stakeholders and to the wider aspirations of that 2017 symposium. It is in memory of Lynn Stout (who died in April 2018) and in gratitude to the staff and Faculty of the Victoria University at Wellington, who generously invited me to participate in an inspiring academic occasion.

160 Victoria University of Wellington and Cornell Law School "Corporations and other legal entities for society and future generations" (Symposium on "legal personality" as a tool to benefit present society, future generations and humanity, Victoria University of Wellington, Wellington, 13 July 2017). 
